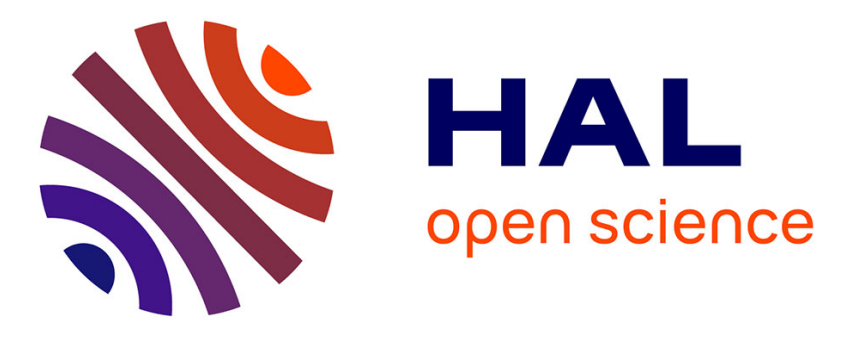

\title{
The MUC4 membrane-bound mucin regulates esophageal cancer cell proliferation and migration properties: Implication for S100A4 protein
}

Emilie Bruyère, Nicolas Jonckheere, Frédéric Frénois, Christophe Mariette, Isabelle van Seuningen

\section{To cite this version:}

Emilie Bruyère, Nicolas Jonckheere, Frédéric Frénois, Christophe Mariette, Isabelle van Seuningen. The MUC4 membrane-bound mucin regulates esophageal cancer cell proliferation and migration properties: Implication for S100A4 protein. Biochemical and Biophysical Research Communications, 2011, pp.325-329. 10.1016/j.bbrc.2011.08.095 . hal-02905689

\section{HAL Id: hal-02905689 \\ https://hal.science/hal-02905689}

Submitted on 29 Sep 2020

HAL is a multi-disciplinary open access archive for the deposit and dissemination of scientific research documents, whether they are published or not. The documents may come from teaching and research institutions in France or abroad, or from public or private research centers.
L'archive ouverte pluridisciplinaire HAL, est destinée au dépôt et à la diffusion de documents scientifiques de niveau recherche, publiés ou non, émanant des établissements d'enseignement et de recherche français ou étrangers, des laboratoires publics ou privés. 


\title{
The MUC4 membrane-bound mucin regulates esophageal cancer cell proliferation and migration properties: Implication for S100A4 protein
}

\author{
Emilie Bruyère $^{\mathrm{a}, \mathrm{b}}$, Nicolas Jonckheere ${ }^{\mathrm{a}, \mathrm{b}}$, Frédéric Frénois ${ }^{\mathrm{a}, \mathrm{b}}$, Christophe Mariette ${ }^{\mathrm{a}, \mathrm{b}, \mathrm{c}}$, \\ Isabelle Van Seuningen ${ }^{\mathrm{a}, \mathrm{b}, *}$ \\ a Inserm, UMR837, Jean-Pierre Aubert Research Center, Team 5 “Mucins, Epithelial Differentiation and Carcinogenesis", rue Polonovski, 59045 Lille Cedex, France \\ ${ }^{\mathrm{b}}$ Université Lille-Nord de France, 1 place de Verdun, 59045 Lille Cedex, France \\ ${ }^{\mathrm{c}}$ Department of Digestive and Oncological Surgery, University Hospital Claude Huriez, 1 place de Verdun, 59045 Lille Cedex, France
}

\section{A R T I C L E I N F O}

\section{Article history:}

Received 16 August 2011

Available online $\mathrm{xxx}$

\section{Keywords:}

Esophagus

Adenocarcinoma

Mucin

MUC4

S100A4

\begin{abstract}
A B S T R A C T
MUC4 is a membrane-bound mucin known to participate in tumor progression. It has been shown that MUC4 pattern of expression is modified during esophageal carcinogenesis, with a progressive increase from metaplastic lesions to adenocarcinoma. The principal cause of development of esophageal adenocarcinoma is the gastro-esophageal reflux, and MUC4 was previously shown to be upregulated by several bile acids present in reflux. In this report, our aim was thus to determine whether MUC4 plays a role in biological properties of human esophageal cancer cells. For that stable MUC4-deficient cancer cell lines (shMUC4 cells) were established using a shRNA approach. In vitro (proliferation, migration and invasion) and in vivo (tumor growth following subcutaneous xenografts in SCID mice) biological properties of shMUC4 cells were analyzed. Our results show that shMUC4 cells were less proliferative, had decreased migration properties and did not express S100A4 protein when compared with MUC4 expressing cells. Absence of MUC4 did not impair shMUC4 invasiveness. Subcutaneous xenografts showed a significant decrease in tumor size when cells did not express MUC4. Altogether, these data indicate that MUC4 plays a key role in proliferative and migrating properties of esophageal cancer cells as well as is a tumor growth promoter. MUC4 mucin appears thus as a good therapeutic target to slow-down esophageal tumor progression.
\end{abstract}

(c) 2011 Elsevier Inc. All rights reserved.

\section{Introduction}

Mucins are large $O$-glycoproteins that can be secreted in the lumen where they participate in mucus formation and in epithelia protection. Mucins may also be membrane-bound and participate in cell signaling and cell-cell or cell-extracellular matrix interactions $[1,2]$. Membrane-bound mucins, to which MUC4 belongs, are normally expressed at the apical membrane of epithelial cells. Because of this localization and their extremely long extracellular domain $(2 \mu \mathrm{m})$ these mucins are considered as receptors and sensors of the external environment. Because of their capacity to interact with oncogenic receptors they also play roles in signal transduction and modulate cellular biological properties [3]. It has also been shown that membrane-bound mucins are often overexpressed in cancer and that they promote tumor progression $[4,5]$.

\footnotetext{
* Corresponding author at: Inserm, UMR837, Jean-Pierre Aubert Research Center, Team 5 "Mucins, Epithelial Differentiation and Carcinogenesis", rue Polonovski, 59045 Lille Cedex, France. Fax: +33 320538562

E-mail address: isabelle.vanseuningen@inserm.fr (I. Van Seuningen).
}

MUC4 is a type-I transmembrane glycoprotein of $930 \mathrm{kDa}$ composed of two subunits: one extracellular highly glycosylated, MUC4 $\alpha$, and one transmembrane subunit, MUC4 $\beta$, that contains three EGF-like domains [2]. An aberrant pattern of expression of MUC4 has been reported in numerous cancers [6] and its overexpression is often correlated with a poor prognosis [7]. In the normal human esophagus the membrane-bound mucin MUC4 is expressed at a very low level whereas in esophageal cancer its expression is progressively increasing from the early metaplastic steps till adenocarcinoma (ADK) [8,9].

Esophageal ADK incidence has been increasing for the last 40 years [10] and up to now, curative treatment is mainly based on extended esophageal resection, in combination with radiation and/or chemotherapy for locally advanced tumors [11]. It is also known that esophageal ADK is induced by a chronic exposure of the distal esophagus to the duodeno-gastro-esophageal reflux [12-14]. This exposure induces the initiation of early carcinogenetic lesions called Barrett esophagus (BE), characterized by an intestinal and/or gastric metaplasia [15]. Under the effects of reflux, these lesions may evolve to low-grade then high-grade dysplasia and finally to ADK [16]. Incidently, MUC4 has been shown in our laboratory to be upregulated by the main bile acids present in 
the reflux (cholic, taurocholic and glycocholic acids) in human esophageal adenocarcinomatous cells $[17,18]$.

In order to improve patient prognosis and therapy, it is now mandatory to better identify actors and molecular mechanisms involved in this carcinogenesis. MUC4 altered pattern of expression and the fact that membrane-bound mucins are known to play a role in tumor progression and metastasis formation in other type of cancers $[4,5,7,19]$ led us to hypothesize that this mucin could also play a key role in esophageal ADK initiation and/or progression.

Having shown a link between reflux, bile acids and MUC4 overexpression in esophageal ADK progression, we thus undertook to study MUC4 effects on the biological properties of human esophageal adenocarcinomatous cells.

\section{Materials and methods}

\subsection{Cell culture}

The OE33 esophageal adenocarcinomatous cell line was cultured as described previously [17]. OE33 cells knocked-down for MUC4 (shMUC4) were established by stable retro-viral infection using a pRetroSuper plasmid (SABiosciences ${ }^{\mathrm{TM}}$ ) containing a sequence targeting MUC4 (5'-AAGTGGAACGAATCGATTCTGTCTCT TGAACAGAATCGATTCGTTCCACTT-3'). The control cells [20] were infected with the corresponding empty vector. Results presented in this study are the means of two representative clones, shMUC4-1 and shMUC4-2, compared to control Mock clones.

\section{2. siRNA (small interfering) assays}

OE33 cells were transfected with S100A4 siRNA from Dharmacon (Epsom, United Kingdom) following the protocol described previously [18]. Controls were performed using a Non-Targeting siRNA (NT) or using the transfection agent alone (Dharmafect1, Dharmacon) [20].

\subsection{Protein extraction and expression}

Total protein extraction and expression was performed and analyzed by Western blotting as described previously [18]. Antibodies used were purchased from Sigma [ $\beta$ actin (A-5441 at 1/ 5000e)], from Santa Cruz Biotechnology [MUC4 (8G7 at 1/500e)] or from Abcam [S100A4 (ab27957 at $\left.1 / 200^{\mathrm{e}}\right)$ ]. Peroxydase-conjugated secondary antibodies (Pierce) were used and chemo-luminescence was visualized using LAS4000 apparatus (Fujifilm).

\subsection{Proliferation}

Cell proliferation was analyzed by counting cells on a Malassez counting chamber. $1.5 \times 10^{5}$ Cells were plated in 6 -well plates and then counted every day. Each experiment was carried out three times in triplicate.

\subsection{Migration}

$2 \times 10^{5}$ Cells were plated on 96-well plates in triplicate, until confluency. Wound was made using the 96-pin WoundMaker device (Essen Bioscience). Plates were then placed in an incubator $\left(5 \% \mathrm{CO}_{2}, 37^{\circ} \mathrm{C}\right)$ into the Incucyte ${ }^{\mathrm{TM}}$ (Essen Bioscience) chamber apparatus. Pictures of wounds were taken every $2 \mathrm{~h}$. The wound closure percentages were observed every $12 \mathrm{~h}$, from 0 to $36 \mathrm{~h}$. Each experiment was performed three times in triplicate.

\subsection{Invasion}

Cell invasion was tested using Boyden Chambers coated with Matrigel $^{\circledR}$ (BD Bioscience). Cells that went through the Matrigel were counted $48 \mathrm{~h}$ later. Invasion index was calculated as recommended by the manufacturer (Invasion/Migration ratio). Each experiment was carried out three times in triplicate.

\subsection{Subcutaneous xenografts}

Subcutaneous xenografts were made by injections of $150 \mu \mathrm{l}$ of RPMI 1640 (Invitrogen) medium containing $4 \times 10^{6}$ OE33 cells and $150 \mu \mathrm{l}$ of Matrigel ${ }^{\circledR}$ (BD 354262, BD Bioscience) into SCID mice maintained in pathogen-free conditions. The tumor progression was followed weekly and the tumor volumes were calculated as width/lengh ${ }^{2}\left(\mathrm{~cm}^{3}\right)$. Ten mice were injected for each cellular clone. All procedures were in accordance with the guideline of animal care committee (Comité Ethique Expérimentation Animale Nord Pas-de-Calais, AF042008).

\subsection{Immunohistochemistry}

MUC4 and S100A4 expression in human tissues with esophageal ADK was studied by automatic and manual immunohistochemistry (IHC), respectively. Manual IHC was performed as described in [21] and automatic IHC with an automated immunostainer (ES, Ventana Medical System, Strasbourg, France) as described in [17]. Antibodies were purchased from Santa Cruz Biotechnology (MUC4, sc-13654 at $1 / 30^{\mathrm{e}}$ ) and from Abcam (S100A4, ab-41532 at $1 / 100^{\mathrm{e}}$ ). Positive controls were included by staining tissues known to express the protein of interest and negative controls were run with $1 \times$ D-PBS instead of primary antibodies.

\subsection{Statistics}

Statistical analyses were carried out with Excel and GraphPad 4.0 Softwares (GraphPad Softwares Inc., La Jolla, USA). Differences in the mean of samples were analyzed by Student $t$ test or one way anova test with selected comparison using tukey post hoc test with differences less than 0.05 considered statistically significant $\left({ }^{*}\right)$. ${ }^{* *}$ Indicates $p<0.01$ and ${ }^{* * *} p<0.001$.

\section{Results}

\subsection{Characterization of shMUC4 OE33 cells}

To study the effects of MUC4 mucin on esophageal cancer cells properties, a stable OE33 shMUC4 cell line was established using shRNA approach (Fig. 1). MUC4 decreased expression in shMUC4 cells compared to Mock clones was confirmed at the protein level (Fig. 1A).

\subsection{Proliferation}

MUC4 role in proliferation was studied by measuring shMUC4 cells capacity to proliferate. MUC4 deficient cells showed decreased proliferation compared to Mock cells as of day 3 (Fig. 1B). This decrease was significant as of day $4(p=0.0159)$ and sustained till day 6 .

\subsection{Migration and invasion}

MUC4 role in migration was studied by using a wound-healing test. These studies indicate that shMUC4 cells have a decreased 


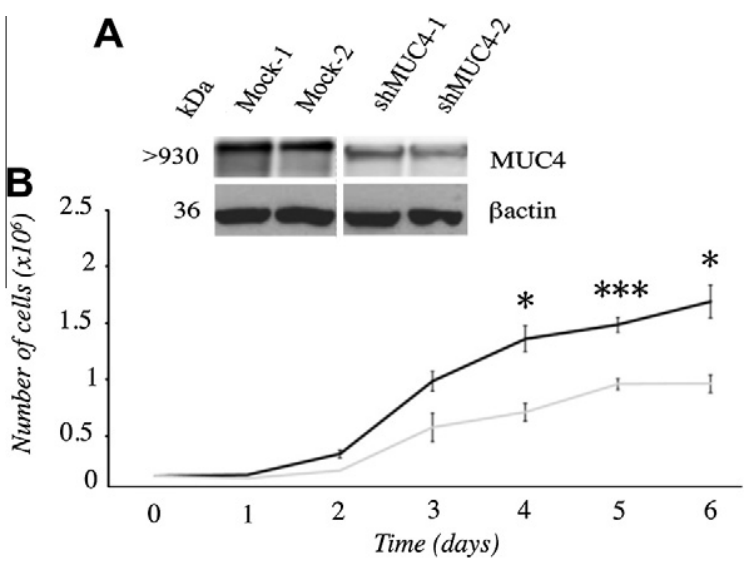

Fig. 1. Expression of MUC4 mucin in OE33 cells. Comparison of two clones of Mock cells transfected with the empty vector pRetroSuper versus two clones of shMUC4 cells. (A) MUC4 protein expression was analyzed by Western blotting. (B) Analysis of the proliferation of OE33 Mock cells (black line) and OE33 shMUC4 cells (grey line). Countings were performed every day during 6 days. *Corresponds to $p \leqslant 0.05$ and ${ }^{* * *} p \leqslant 0.001$ (Student $t$ test).

capacity to close the wound when compared to Mock cells (Fig. 2A). This result was significant as of $36 \mathrm{~h}$ after wound formation $(p=0.03)$ (Fig. 2B).

The role of MUC4 in OE33 capacity to invade a matrix was then studied using Boyden Chambers coated with Matrigel ${ }^{\circledR}$. No significant difference between shMUC4 and Mock cells was found (Fig. 2C).

\subsection{Subcutaneous xenografts}

Having shown in vitro that MUC4 deficient cells were less proliferative than MUC4 expressing cells, we then studied their growth properties in vivo following subcutaneous xenografts in SCID mice (Fig. 3). As of 3 weeks post-injection, shMUC4 tumors $\left(0.33 \pm 0.008\right.$ and $\left.0.25 \pm 0.08 \mathrm{~cm}^{3}\right)$ were significantly smaller than Mock tumors $\left(0.95 \pm 0.12\right.$ and $\left.0.85 \pm 0.19 \mathrm{~cm}^{3}\right)$ (Fig. 3A). The difference between shMUC4 and Mock tumor volumes became highly significant as of 4 weeks post-injection ( $p \leqslant 0.001$ ) (Fig. 3B).

A
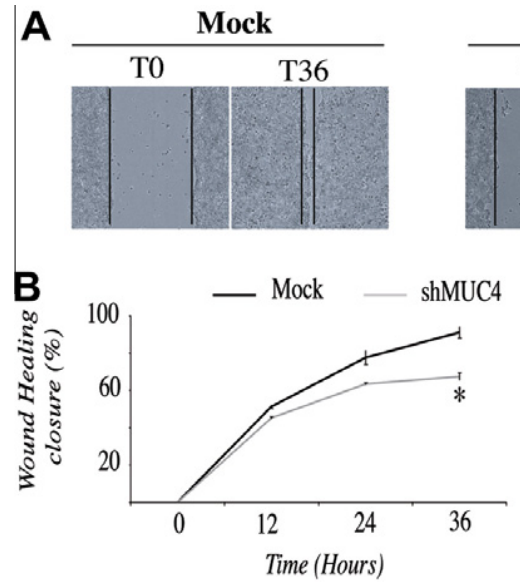

C

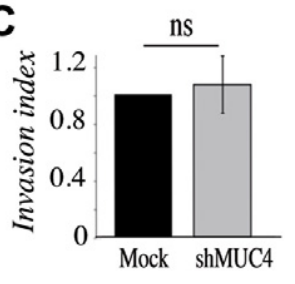

Fig. 2. Analysis of the migration properties of OE33 Mock and shMUC4 cells using a wound-healing test. (A) Photographies of wound closure at T0 and T36 h. (B) Diagram representing the percentage of wound-healing closure from T0 to T36 h. (C) Calculation of the invasion index of control Mock cells and shMUC4 cells using Boyden Chambers coated with Matrigel ${ }^{\circledR}$. The invasion index is the ratio of the number of invasive cells reported to the number of migrating cells. ${ }^{*}$ Corresponds to $p \leqslant 0.05$ (Student $t$ test).
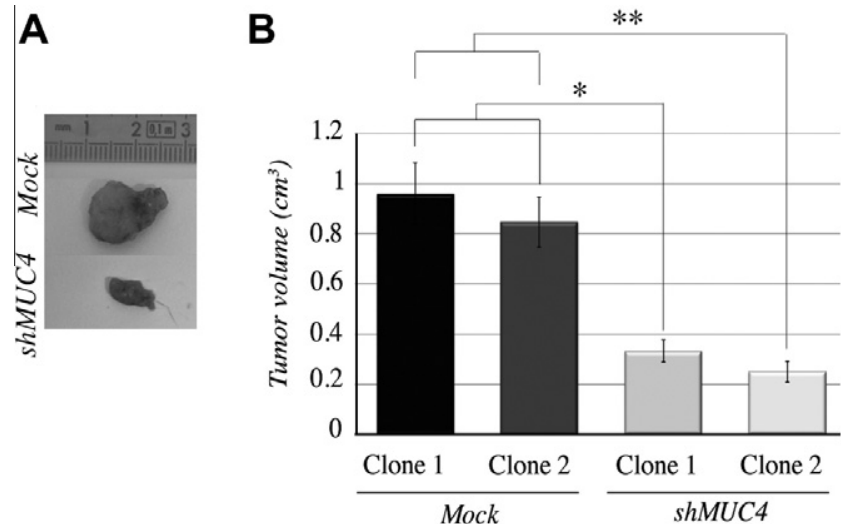

Fig. 3. In vivo analysis of the role of MUC4 on tumor progression following subcutaneous xenografts in SCID mice. (A) Photography of 4 weeks tumors of Mock and shMUC4 xenografts. (B) Means of tumor volumes in $\mathrm{cm}^{3}$ of 4 weeks Mock and shMUC4 xenografts. ${ }^{*}$ Corresponds to $p \leqslant 0.05$ and ${ }^{* *} p \leqslant 0.01$ (one way anova with tukey post hoc)

\subsection{MUC4 regulates S100A4 expression}

In order to decipher the mechanisms that could mediate MUC4 effects on OE33 cancer cells, we searched for tumor-associated proteins overexpressed in MUC4-expressing esophageal cancer. For that, we performed a microarray study on esophageal tissues from rats in which we surgically-induced esophageal ADK (Isabelle Van Seuningen, personal communication) and in human tissues from patients with esophageal cancer. In both cases, we found overexpression of the calcium-binding protein S100A4 expression in MUC4-expressing esophageal cancer (Fig. 4A). We thus studied S100A4 expression at the protein level in shMUC4 compared to Mock cells and found that, in shMUC4 cells, the S100A4 expression was strongly decreased compared to Mock cells (Fig. 4B).

Having shown a molecular link between MUC4 and S100A4, we then studied S100A4 role on OE33 cell properties using a siRNA approach. The results indicate that decreased expression of S100A4 reduced significantly the capacity of OE33 cells to proliferate $(p=0.0348)$ (Fig. 4C) and to migrate $(p=0.0443)$ (Fig. 4D) when compared to control cells.

\section{Discussion}

In this report we show that decreased expression of MUC4 in OE33 cells strongly impaired their in vitro proliferation and migration properties whereas invasion was unchanged. In vivo SC tumors deficient for MUC4 were also smaller than those expressing MUC4. These results confirm the fact that MUC4 is an oncoprotein involved in many epithelial cancers as it has been shown that MUC4 could regulate biological properties of other cell type as pancreatic cancer cells [6,22-24]. Aberrant expression of MUC4 is indeed observed in several type of epithelial cancers and inflammatory diseases [6] like carcinomas of the pancreas, ovary, breast, lung and gall bladder. Some studies have shown that over-expression of MUC4 in pancreatic cancer cells promotes tumor growth by increasing cell proliferation and decreasing cell apoptosis [6]. Moreover, the loss of MUC4 in pancreatic cancer cells decreased cell proliferation, motility and aggregation [3,7]. It has also been shown that MUC4 can induce an epithelium-mesenchyme transition in ovarian cancer cells, and thus promotes metastasis formation [25]. In this report, we show that MUC4 is also involved in esophageal cancer cell behavior. Altogether, these data point to a major role for MUC4 in epithelial tumorigenesis whenever MUC4 
A

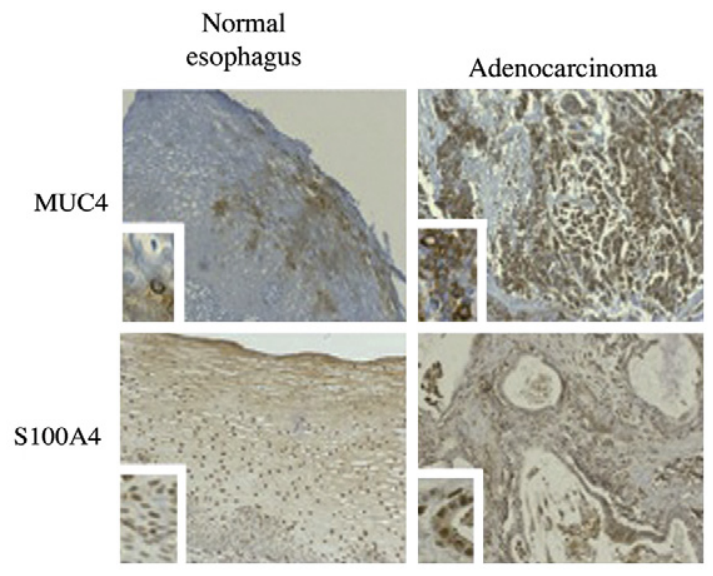

B
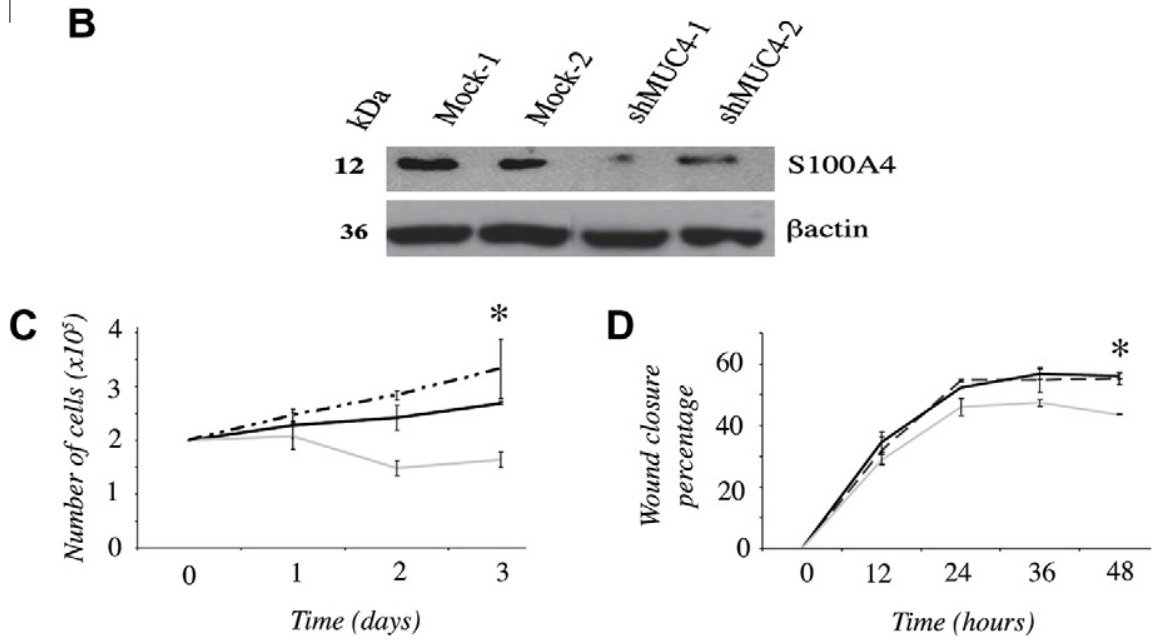

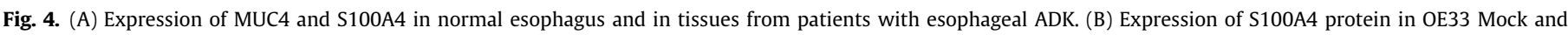

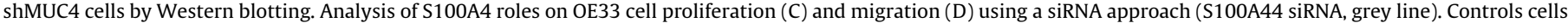

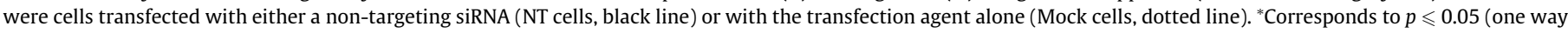
anova with tukey post hoc).

is over-expressed. Lack of MUC4 did not lead to any significant alteration of invasion. We previously showed no significant correlation between MUC4 staining in Barrett-associated esophageal ADK and depth of tumor invasion as well as lymph node metastasis [26]. MUC4-induced steric hindrance may block migration properties by blocking interaction with extracellular matrix. One could hypothesize that mechanisms of matrix degradation, such as metallo-protease proteins (MMP), may not be affected by lack of MUC4 and therefore could explain why we did not observe any difference in invasion.

Interestingly, we found that altered properties of OE33 esophageal cancer cells related to MUC4 deficiency correlated to that of the calcium-binding protein S100A4. This protein is known to have many roles in cancer cell properties [27], particularly in metastasis formation [28-30]. Our data (Fig. 4A) and a study on patient biopsies showed that S100A4 is expressed in esophageal ADK [31], suggesting that this protein plays a critical role in this carcinogenesis. Our results are thus in favor of a regulation of S100A4 by MUC4 that would lead to decreased proliferation and migration properties of esophageal cancer cells. These results are in agreement with previous works carried out in pancreatic cancer cells in which authors had shown that S100A4 was involved in cell growth and motility [32].

In conclusion, our results show that the MUC4 membranebound mucin regulates in vitro and in vivo biological properties of esophageal cancer cells and that these effects may be partly mediated by the calcium-binding protein S100A4.

\section{Acknowledgments}

We thank Dr. Jean-Luc Desseyn (Inserm U995, Lille, France) and Dr. David Bernard (Inserm UMR1052/CNRS5286, Centre Léon Bérard, Lyon, France) for their help in establishing the stable MUC4 deficient cell lines. This work was supported by La Fondation pour l'Avenir and La Fondation pour la Recherche Médicale (Equipe FRM 2010, Christophe Mariette). Emilie Bruyère is the recipient of a Ph.D. Fellowship from Le Centre Hospitalier Régional Universitaire de Lille and Région Nord-Pas de Calais. Nicolas Jonckheere is the recipient of a Ligue Nationale Contre le Cancer postdoctoral fellowship. Frédéric Frénois is the recipient of a Fondation pour la Recherche Médicale postdoctoral fellowship. Isabelle Van Seuningen is the recipient of a "Contrat Hospitalier de Recherche Translationnelle"/CHRT 2010, AVIESAN.

\section{References}

[1] K.L. Carraway, V.P. Ramsauer, B. Haq, C.A. Carothers Carraway, Cell signaling through membrane mucins, BioEssays 25 (2002) 66-71.

[2] N. Jonckheere, I. Van Seuningen, The ever growing family of membrane-bound mucins, in: I. Van Seuningen (Ed.), The Epithelial Mucins: Structure/Function. Roles in Cancer and Inflammatory Diseases, Research Signpost, Kerala, India, 2008, pp. 17-38.

[3] N. Jonckheere, I. Van Seuningen, The membrane-bound mucins: from cell signalling to transcriptional regulation and expression in epithelial cancers, Biochimie 92 (2010) 1-11.

[4] D.W. Kufe, Mucins in cancer: function, prognosis and therapy, Nat. Rev. Cancer 9 (2009) 874-885. 
[5] M.A. Hollingsworth, B.J. Swanson, Mucins in cancer: protection and control of the cell surface, Nat. Rev. Cancer 4 (2004) 45-60.

[6] P. Chaturvedi, A.P. Singh, S.K. Batra, Structure, evolution, and biology of the MUC4 mucin, FASEB J. 22 (2008) 966-981.

[7] N. Jonckheere, I. Van Seuningen, The membrane-bound mucins: how large $O$ glycoproteins play key roles in epithelial cancers and hold promise as biological tools for gene-based and immunotherapies, Crit. Rev. Oncog. 14 (2008) 177-196.

[8] G.S. Arul, M. Moorghen, N. Myerscough, D.A. Alderson, R.D. Spicer, A.P. Corfield, Mucin gene expression in Barrett's oesophagus: an in situ hybridisation and immunohistochemical study, Gut 47 (2000) 753-761.

[9] P. Guillem, V. Billeret, M.P. Buisine, J.F. Flejou, M. Lecomte-Houcke, P. Degand, J.P. Aubert, J.P. Triboulet, N. Porchet, Mucin gene expression and cell differentiation in human normal, premalignant and malignant esophagus, Int. J. Cancer 88 (2000) 856-861.

[10] R.S. Holmes, T.L. Vaughan, Epidemiology and pathogenesis of esophageal cancer, Semin. Radiat. Oncol. 17 (2007) 2-9.

[11] C. Mariette, G. Piessen, N. Briez, C. Gronnier, J.P. Triboulet, Oesophagogastric junction adenocarcinoma: which therapeutic approach?, Lancet Oncol 12 (2011) 296-305.

[12] W.K. Kauer, J.H. Peters, T.R. DeMeester, H. Feussner, A.P. Ireland, H.J. Stein, R.J Siewert, Composition and concentration of bile acid reflux into the esophagus of patients with gastroesophageal reflux disease, Surgery 122 (1997) 874-881.

[13] C.P. Wild, L.J. Hardie, Reflux, Barrett's oesophagus and adenocarcinoma: burning questions, Nat. Rev. Cancer 3 (2003) 676-684.

[14] M. Fein, J. Maroske, K.H. Fuchs, Importance of duodenogastric reflux in gastrooesophageal reflux disease, Br. J. Surg. 93 (2006) 1475-1482.

[15] B.J. Colleypriest, S.G. Ward, D. Tosh, How does inflammation cause Barrett's metaplasia?, Curr Opin. Pharmacol. 9 (2009) 721-726.

[16] A.T. Prach, T.A. MacDonald, D.A. Hopwood, D.A. Johnston, Increasing incidence of Barrett's oesophagus: education, enthusiasm, or epidemiology?, Lancet 350 (1997) 933

[17] C. Mariette, M. Perrais, E. Leteurtre, N. Jonckheere, B. Hemon, P. Pigny, S. Batra, J.P. Aubert, J.P. Triboulet, I. Van Seuningen, Transcriptional regulation of human mucin MUC4 by bile acids in oesophageal cancer cells is promoterdependent and involves activation of the phosphatidylinositol 3-kinase signalling pathway, Biochem. J. 377 (2004) 701-708.

[18] G. Piessen, N. Jonckheere, A. Vincent, B. Hemon, M.P. Ducourouble, M.C. Copin, C. Mariette, I. Van Seuningen, Regulation of the human mucin MUC4 by taurodeoxycholic and taurochenodeoxycholic bile acids in oesophageal cancer cells is mediated by hepatocyte nuclear factor 1alpha, Biochem. J. 402 (2007) 81-91.

[19] A.P. Singh, S. Senapati, M.P. Ponnusamy, M. Jain, S.M. Lele, J.S. Davis, S Remmenga, S.K. Batra, Clinical potential of mucins in diagnosis, prognosis, and therapy of ovarian cancer, Lancet Oncol. 9 (2008) 1076-1085.

[20] A.G. Gilman, M.I. Simon, H.R. Bourne, B.A. Harris, R. Long, E.M. Ross, J.T. Stull, R. Taussig, A.P. Arkin, M.H. Cobb, J.G. Cyster, P.N. Devreotes, J.E. Ferrell, D. Fruman, M. Gold, A. Weiss, M.J. Berridge, L.C. Cantley, W.A. Catterall, S.R. Coughlin, E.N. Olson, T.F. Smith, J.S. Brugge, D. Botstein, J.E. Dixon, T. Hunter,
R.J. Lefkowitz, A.J. Pawson, P.W. Sternberg, H. Varmus, S. Subramaniam, R.S. Sinkovits, J. Li, D. Mock, Y. Ning B. Saunders, P.C. Sternweis, D. Hilgemann, R.H. Scheuermann, D. DeCamp, R. Hsueh, K.M. Lin, Y. Ni, W.E. Seaman, P.C. Simpson, T.D. O'Connell, T. Roach, S. Choi, P. Eversole-Cire, I. Fraser, M.C. Mumby, Y. Zhao, D. Brekken, H. Shu, T. Meyer, G. Chandy, W.D. Heo, J. Liou, N. O’Rourke, M. Verghese, S.M. Mumby, H. Han, H.A. Brown, J.S. Forrester, P. Ivanova, S.B. Milne, P.J. Casey, T.K. Harden, J. Doyle, M.L. Gray, S. Michnick, M.A. Schmidt, M. Toner, R.Y. Tsien, M. Natarajan, R. Ranganathan, G.R. Sambrano, Overview of the alliance for cellular signaling, Nature 420 (2002) 703-706.

[21] M. van der Sluis, M.H. Melis, N. Jonckheere, M.P. Ducourouble, H.A. Buller, I. Renes, A.W. Einerhand, I. Van Seuningen, The murine Muc2 mucin gene is transcriptionally regulated by the zinc-finger GATA- 4 transcription factor in intestinal cells, Biochem. Biophys. Res. Commun. 325 (2004) 952-960.

[22] N. Jonckheere, M. Perrais, C. Mariette, S.K. Batra, J.P. Aubert, P. Pigny, I. Van Seuningen, A role for human MUC4 mucin gene, the ErbB2 ligand, as a target of TGF-beta in pancreatic carcinogenesis, Oncogene 23 (2004) 5729-5738.

[23] V. Fauquette, M. Perrais, S. Cerulis, N. Jonckheere, M.P. Ducourouble, J.P. Aubert, P. Pigny, I. Van Seuningen, The antagonistic regulation of human MUC4 and ErbB-2 genes by the Ets protein PEA3 in pancreatic cancer cells: implications for the proliferation/differentiation balance in the cells, Biochem. J. 386 (2005) 35-45.

[24] P. Chaturvedi, A.P. Singh, N. Moniaux, S. Senapati, S. Chakraborty, J.L. Meza, S.K Batra, MUC4 mucin potentiates pancreatic tumor cell proliferation, survival, and invasive properties and interferes with its interaction to extracellular matrix proteins, Mol. Cancer Res.: MCR 5 (2007) 309-320.

[25] M.P. Ponnusamy, I. Lakshmanan, M. Jain, S. Das, S. Chakraborty, P. Dey, S.K. Batra, MUC4 mucin-induced epithelial to mesenchymal transition: a novel mechanism for metastasis of human ovarian cancer cells, Oncogene 29 (2010) 5741-5754.

[26] G. Piessen, A. Wacrenier, N. Briez, J.P. Triboulet, I. Van Seuningen, C. Mariette, Clinical impact of MUC1 and MUC4 expression in Barrett-associated oesophageal adenocarcinoma, J. Clin. Pathol. 62 (2009) 1144-1146.

[27] G.V. Sherbet, M.S. Lakshmi, S100A4 (MTS1) calcium binding protein in cancer growth, invasion and metastasis, Anticancer Res. 18 (1998) 2415-2421.

[28] Z.H. Li, A.R. Bresnick, The S100A4 metastasis factor regulates cellular motility via a direct interaction with myosin-IIA, Cancer Res. 66 (2006) 5173-5180.

[29] G.V. Sherbet, Metastasis promoter S100A4 is a potentially valuable molecular target for cancer therapy, Cancer Lett. 280 (2009) 15-30.

[30] H.Y. Zhang, X.Z. Zheng, X.H. Wang, X.Y. Xuan, F. Wang, S.S. Li, S100A4 mediated cell invasion and metastasis of esophageal squamous cell carcinoma via the regulation of MMP-2 and E-cadherin activity, Mol. Biol. Rep. (2011).

[31] O.J. Lee, S.M. Hong, M.H. Razvi, D. Peng, S.M. Powell, M. Smoklin, C.A. Moskaluk, W. El-Rifai, Expression of calcium-binding proteins S100A2 and S100A4 in Barrett's adenocarcinomas, Neoplasia 8 (2006) 843-850.

[32] T. Tabata, N. Tsukamoto, A.A. Fooladi, S. Yamanaka, T. Furukawa, M. Ishida, D. Sato, Z. Gu, H. Nagase, S. Egawa, M. Sunamura, A. Horii, RNA interference targeting against S100A4 suppresses cell growth and motility and induces apoptosis in human pancreatic cancer cells, Biochem. Biophys. Res. Commun. 390 (2009) 475-480. 